\title{
Keragaman Genetik 19 Genotipe Cabai Rawit Merah (Capsicum frutescens) serta Ketahanannya terhadap Kutu Daun (Aphis gossypii)
}

\section{Genetic Variability of Nineteen Birds Eye Chili Genotypes and Their Resistance to Melon Aphids (Aphis gossypii)}

\section{Estriana Riti ${ }^{1}$, Muhamad Syukur ${ }^{2 *}$, Awang Maharijaya ${ }^{2}$, dan Purnama Hidayat ${ }^{3}$}

\author{
${ }^{1}$ Program Studi Pemuliaan dan Bioteknologi Tanaman, Sekolah Pascasarjana, Institut Pertanian Bogor \\ ${ }^{2}$ Departemen Agronomi dan Hortikultura, Fakultas Pertanian, Institut Pertanian Bogor \\ (Bogor Agricultural University), Jl. Meranti, Kampus IPB Darmaga, Bogor 16680, Indonesia \\ ${ }^{3}$ Departemen Proteksi Tanaman, Fakultas Pertanian, Institut Pertanian Bogor \\ (Bogor Agricultural University), Jl. Kamper, Kampus IPB Darmaga, Bogor 16680, Indonesia
}

Diterima 28 Maret 2018/Disetujui 5 Oktober 2018

\begin{abstract}
The information on birds eye chili (Capsicum frutescens L.) resistance to melon aphids (Aphis gossypii) is rarely reported. Objectives of this research were to evaluate genetic variability of 19 genotypes bird chili and identify the potential genotypes resistant to $\underline{A}$. gossypii. This research consisted of two experiments. The first experiment was conducted in AprilDecember 2015 at Leuwikopo Experimental Field, Faculty of Agriculture IPB. Genetic materials used were 19 genotypes of bird chili from Plant Breeding Laboratory IPB which were planted from seedling stage until harvesting stage. The second experiment was conducted in May 2017-May 2018 at Faculty of Agriculture, IPB Darmaga Campus. Material used were 19 genotypes of bird chili at seedling stage, and melon aphids which were collected from Leuwikopo Experimental Field IPB. Melon aphid infestation method used no-choice test. The results showed the genetic variability of bird chili had more than 0.30 coefficient of dissimilarity. Genetic variability for canopy width, anther length, fruit weight, and fruit length were classified to broad, but total fruit weight per plant was classified to narrow. There were six genotypes clasified resistant to melon aphid, i.e., C332, C343, C333, C334, C290, C346. The potential genotypes for breeding program of bird chili resistant to melon aphid were C343 and C334.
\end{abstract}

Keywords: Aphis gossypii, Capsicum frutescens, cluster, resistant variety

\section{ABSTRAK}

Informasi mengenai ketahanan cabai rawit merah (Capsicum frutescens) terhadap kutu daun (Aphis gossypii) belum banyak dilaporkan. Tujuan penelitian ini adalah untuk mengevaluasi keragaman genetik 19 genotipe cabai rawit merah dan mendapatkan genotipe potensial yang tahan terhadap kutu daun. Penelitian terdiri atas dua percobaan. Percobaan pertama dilaksanakan pada bulan April-Desember 2015 di KP Leuwikopo, Faperta IPB. Materi genetik yang digunakan adalah 19 genotipe cabai rawit merah koleksi plasma nutfah Labdik Pemuliaan Tanaman IPB yang ditanam sejak fase bibit hingga fase panen buah. Percobaan kedua dilaksanakan Mei 2016-Mei 2017 di areal kampus, Faperta IPB. Bahan yang digunakan adalah bibit 19 genotipe cabai rawit merah serta kutu daun hasil koleksi dari KP Leuwikopo, Faperta IPB. Metode infestasi kutu daun adalah no-choice test. Hasil penelitian menunjukkan bahwa keragaman cabai rawit merah memiliki koefisien ketidakmiripan lebih dari 0.30. Keragaman genetik karakter lebar tajuk, panjang anter, bobot per buah, panjang buah termasuk kategori luas, sedangkan bobot buah total per tanaman termasuk sempit. Sebanyak enam genotipe teridentifikasi tahan kutu daun yaitu C332, C343, C333, C334, C290, C346. Berdasarkan hasil evaluasi diketahui bahwa genotipe C343 dan C334 layak dikembangkan sebagai varietas tahan kutu daun dan berdaya hasil tinggi.

Kata kunci: Aphis gossypii, Capsicum frutescens, klaster, varietas tahan

* Penulis untuk korespondensi. e-mail: muhsyukur@ipb.ac.id 


\section{PENDAHULUAN}

Di Indonesia dikenal dua tipe cabai rawit yaitu rawit merah (Capsicum frutescens L.) dan rawit hijau (Capsicum annuum L.) (Undang et al., 2015; Hakim et al., 2018). Perbedaan keduanya berdasarkan siklus hidup dan tingkat kepedasan rasa. Rawit merah memiliki siklus hidup tahunan (perennial), sedangkan rawit hijau memiliki siklus hidup semusim (annual). Tingkat kepedasan rasa cabai rawit merah lebih pedas dari pada cabai rawit hijau. Tingkat kepedasan tersebut diketahui dari kandungan capsaicin pada rawit merah sebesar 104,300-141,200 Scoville heat unit (SHU) dan rawit hijau sebesar 26,600-39,100 SHU (Sanatombi dan Sharma, 2008).

Cabai rawit merah banyak dibudidayakan pada daerah marginal, sehingga daya hasilnya kurang optimal, padahal komoditas cabai rawit merah memiliki potensi untuk menyangga ekonomi masyarakat menengah ke bawah melalui sistem tanam agroforestri (Buyinza dan Mugagga, 2010). Proyeksi produksi cabai rawit nasional pada tahun 2020 diperkirakan 1.03 juta ton. Namun saat ini rata-rata nasional produktivitasnya masih rendah yaitu sebesar 6 ton $\mathrm{ha}^{-1}$, padahal potensinya dapat mencapai 21 ton $\mathrm{ha}^{-1}$. Cara untuk memenuhi target tersebut adalah melalui peningkatan potensi produktivitas cabai rawit dengan penanaman varietas unggul baru (Nuryati et al., 2016).

Salah satu hama penting dan dapat menurunkan tingkat produktivitas pada budidaya cabai rawit adalah adalah kutu daun (Aphis gossypii) karena populasinya paling banyak diantara spesies hama Aphis lainnya (Nelly et al., 2015). Hama ini menghisap hasil fotosintesis pada floem dan menghasilkan sekresi berupa embun madu yang mengandung gula. Embun madu tersebut dapat berasosiasi dengan cendawan dan mengakibatkan terbentuknya embun jelaga. Embun jelaga akan menutup permukaan daun sehingga penyerapan sinar matahari terhambat. Hama ini juga menjadi vektor virus dari famili Caulimoviridae dan Luteoviridae (Kanakala dan Ghanim, 2016) yang dapat menurunkan hasil cabai rawit hingga 58\% (Sukada et al., 2014). Tingkat kehilangan hasil akibat serangan kutu daun secara langsung dilaporkan dapat mencapai $61.97 \%$ (Sudrajat, 2008).

Ketahanan tanaman terhadap serangga hama termasuk kutu daun A. gossypii terbagi menjadi tiga kriteria yaitu antixenosis, antibiosis, dan toleran. Daryanto et al. (2017a) menerangkan antixenosis (non-preference) sebagai mekanisme ketahanan yang memanfaatkan morfologi, fenologi, dan aroma tanaman untuk mencegah kehadiran hama. Antibiosis adalah kemampuan tanaman untuk mencegah atau menghambat hama melakukan proses biologi pada tanaman seperti menurunkan tingkat reproduksi hama.

Informasi mengenai keragaman intraspesies pada cabai rawit merah masih terbatas, demikian pula informasi ketahanan antibiosis terhadap hama $A$. gossypii, sehingga penelitian ini menjadi penting untuk dilakukan. Tujuan kegiatan penelitian ini adalah mendapatkan informasi keragaman genetik 19 genotipe cabai rawit merah dan mendapatkan kandidat genotipe yang berpotensi sebagai material genetik dalam program pemuliaan cabai rawit merah dan memiliki ketahanan antibiosis terhadap kutu daun.

\section{BAHAN DAN METODE}

\section{Karakterisasi 19 Genotipe di Lapang}

Percobaan dilakukan di KP Leuwikopo, Fakultas Pertanian, Institut Pertanian Bogor, pada bulan April hingga Desember 2015. Materi genetik yang digunakan adalah 19 genotipe cabai rawit merah yang terdiri dari tiga genotipe introduksi (C61, C139, C321) dan 16 genotipe lokal (C163, C190, C289, C290, C295, C323, C330, C332, C333, C334, C337, C339, C343, C344, C346, C350). Seluruh genotipe merupakan varietas komersil dan lanras. Percobaan menggunakan rancangan kelompok lengkap teracak (RKLT) faktor tunggal (genotipe) yang diulang tiga kali sebagai kelompok. Total terdapat 57 satuan percobaan. Populasi tanaman tiap satuan percobaan sebanyak 20 tanaman, sehingga total terdapat 1,140 tanaman.

Pelaksanaan penelitian dilakukan dari mulai penyemaian benih hingga panen buah matang sehat. Perawatan tanaman meliputi penyiraman, pemupukan NPK, dan pengendalian hama menggunakan insektisida. Pengamatan dilakukan pada lima karakter kualitatif (warna hipokotil, warna anter, bentuk buah dalam penampang membujur, bentuk ujung buah, warna buah sebelum masak) dan lima karakter kuantitatif (lebar tajuk, panjang anter, bobot per buah, panjang buah, dan bobot buah total per tanaman). Karakter tersebut dipilih untuk mewakili keragaman karakter vegetatif, karakter generatif, dan karakter daya hasil pada cabai rawit merah.

Analisis data meliputi analisis klaster menggunakan perangkat lunak STAR, analisis ragam (uji-F) dan uji jarak berganda duncan menggunakan perangkat lunak SAS portable versi 9.13. Pendugaan nilai ragam genetik, standar deviasi ragam genetik dan heritabilitas arti luas dilakukan menggunakan rumus berturut-turut:

$\sigma^{2} \mathrm{~g}=(\mathrm{KTg}-\mathrm{KTe}) / 3, \sigma \sigma_{\mathrm{G}}^{2}=\sqrt{\frac{2}{r^{2}}\left[\frac{K T_{G}^{2}}{d b_{G}+2}+\frac{K T_{E}^{2}}{d b_{E}+2}\right]}$,

$\mathrm{h}^{2} \mathrm{bs}=\sigma^{2} \mathrm{~g} / \sigma^{2} \mathrm{p} \times 100 \%$ dimana $\sigma^{2} \mathrm{~g}$ : ragam genetik, KTg: Kuadrat tengah genotipe, KTe: Kuadrat tengah eror, r: ulangan, dbG: derajat bebas genotipe, dbE: derajat bebas eror, dan $\sigma^{2} \mathrm{p}$ : ragam fenotipe (Syukur et al., 2011). Klasifikasi nilai heritabilitas ditetapkan berdasarkan Syukur et al. (2015) yaitu rendah $\left(\mathrm{h}^{2} \mathrm{bs}<20 \%\right)$, sedang $\left(20 \%<\mathrm{h}^{2} \mathrm{bs}\right.$ $<50 \%$ ) dan tinggi $\left(\mathrm{h}^{2} \mathrm{bs}>50 \%\right)$. Kriteria keragaman genetik yaitu sempit $=\sigma^{2} \mathrm{~g}<2 \sigma \sigma^{2} \mathrm{G}$ dan luas $=\sigma^{2} \mathrm{~g}>2 \sigma_{\sigma_{\mathrm{G}}}{ }^{2}$.

\section{Uji Ketahanan terhadap Kutu Daun $\underline{\text { A. gossypii }}$}

Percobaan dilakukan pada bulan Mei 2016 hingga Mei 2017. Materi genetik yang digunakan adalah benih 19 genotipe cabai rawit merah hasil koleksi plasma nutfah seperti pada Percobaan 1. Sampel spesies kutu daun $A$. 
gossypii diambil dari pertanaman cabai rawit merah di Kebun Percobaan Leuwikopo, Darmaga, Bogor pada bulan April 2016. Identifikasi spesies A. gossypii menggunakan kunci identifikasi Blackman dan Eastop (2000) bertempat di Laboratorium Biosistematik Serangga, Departemen Proteksi Tanaman, Fakultas Pertanian, IPB.

Perbanyakan $A$. gossypii dilakukan pada tanaman cabai rawit merah yang disungkup plastik dan kain dengan kerapatan 50 mesh. Tanaman dipelihara dalam ruang terbuka beratap dengan kondisi iklim mikro alami di Node C L6, Departemen Agronomi dan Hortikultura, IPB. Lokasi penelitian berada di dataran rendah. Infestasi kutu daun menggunakan metode no-choice test. Metode tersebut dipilih untuk merepresentasikan pola budidaya monokultur sehingga pengamatan dapat difokuskan pada pengaruh antibiosis terhadap populasi hama (Maharijaya, 2013). Stadia kutu daun yang diinfestasikan adalah imago tak bersayap sebanyak 5 ekor per tanaman. Bibit cabai rawit merah yang digunakan berumur 5 minggu setelah semai (MSS) atau telah memiliki 4-6 helai daun (Daryanto et al., 2017b), selanjutnya tanaman ditutup sungkup plastik berdiameter dan tinggi $30 \mathrm{~cm}$ serta tertutup kain dengan kerapatan 50 mesh selama 4 minggu.

Rancangan yang digunakan adalah RKLT faktor tunggal yang diulang tiga kali dengan genotipe sebagai faktor serta ulangan sebagai kelompok. Masing-masing ulangan terdiri atas 1 bibit cabai rawit yang telah memiliki 4-6 helai daun sejati, sehingga total terdapat 57 tanaman. Varietas komersil dan lanras memiliki konstitusi genetik yang stabil dan homogen, sehingga nilai pengamatan antar tanaman tidak berbeda nyata. Jumlah derajat bebas galat (db galat) yang diperoleh dari 19 perlakuan (genotipe) dan 3 ulangan adalah 38 sehingga cukup representatif menggambarkan penelitian. Pemeliharaan tanaman meliputi penyiraman menggunakan air yang dicampur nutrisi AB dengan konsentrasi 750 ppm sebanyak $250 \mathrm{~mL}$ per tanaman dengan frekuensi dua hari sekali serta tidak ada aplikasi insektisida. Pengamatan populasi dilakukan pada hari ke-28 setelah infestasi yaitu dengan menghitung jumlah $A$. gossypii pada tanaman (Saljoki et al., 2013) karena pada hari ke-28 kutu daun telah menyelesaikan satu siklus hidupnya.

Penelitian spesifik mengenai penentuan kriteria ketahanan cabai rawit merah terhadap kutu daun $A$. gosypii ataupun ambang kerugian ekonominya belum ditetapkan, sehingga perlu dilakukan pendekatan penentuan kriteria ketahanan dari spesies tanaman dan spesies hama terdekatnya. Penentuan kriteria ketahanan dalam penelitian ini diadaptasi dari cabai spesies $C$. annuum dan kutu daun spesies Myzus persicae melalui penelitian Moekasan et al. (2015) dan Sudrajat (2008). Ambang pengendalian hama kutu daun pada cabai adalah 20 ekor per tanaman dan ambang kehilangan hasil nyata adalah 64 ekor kutu daun per tanaman. Informasi tersebut digunakan untuk menyusun kriteria ketahanan yaitu tahan ( $0-\leq 20$ ekor per tanaman), intermediet ( $21-\leq 63$ ekor per tanaman), dan rentan ( $\geq 64$ ekor per tanaman).

\section{HASIL DAN PEMBAHASAN}

\section{Keragaman Karakter Kualitatif dan Kuantitatif}

Keragaman plasma nutfah dapat dikelompokkan menggunakan analisis klaster berhierarki (Dutta et al., 2017). Hasil penelitian mengenai keragaman 10 karakter dari 19 genotipe cabai rawit merah menunjukkan skala ketidakmiripan lebih dari 0.30 (30\%) yang mana lebih besar dari penelitian yang dilakukan Dutta et al. (2017) dan Lima et al. (2017). Pemisahan genotipe pada skala 0.25 (25\%) menunjukkan adanya tujuh klaster yaitu lima klaster terdiri atas 2-6 genotipe serta dua klaster terdiri atas 1 genotipe (Gambar 1). Klaster I terdiri atas tiga genotipe yaitu C332, C139, dan C61 memiliki persamaan karakter hipokotil berwarna hijau, bentuk buah moderatly triangular dan warna buah sebelum masak adalah hijau. Klaster II dan IV terdiri

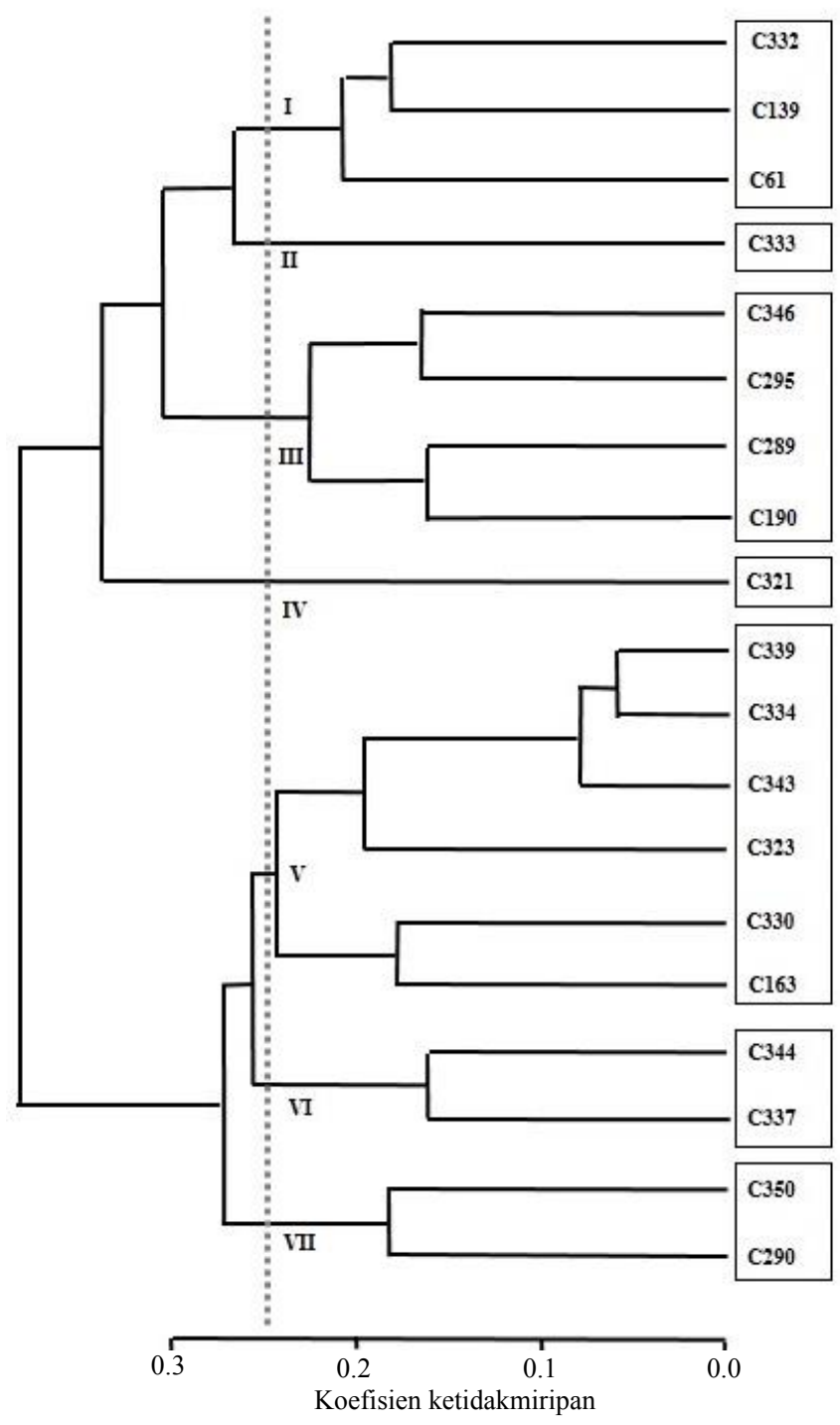

Gambar 1. Analisis gerombol cabai rawit merah menggunakan metode agglomerative average linkage dan koefisien ketidakmiripan Gower 
dari satu genotipe yaitu C333 dan C321 dengan ciri khas masing-masing adalah bentuk buah cordate dan hipokotil berwarna ungu. Klaster VI terdiri dari dua genotipe yaitu C344 dan C337 memiliki persamaan ciri hipokotil berwarna hijau, anter berwarna ungu, bentuk buah moderately triangular, dan warna buah sebelum masak putih kehijauan. Klaster VII terdiri dari dua genotipe yaitu C350 dan C290 memiliki ciri hipokotil berwarna hijau, warna anter hijau, dan bentuk ujung buah melingkar. Klaster III dan V masingmasing terdiri dari empat dan enam genotipe berturut-turut C346, C295, C289, C190, dan C339, C334, C343, C323, C330, C163. Klaster III dan V memiliki perbedaan dalam kelompok pada tiap karakternya kecuali warna hipokotil yang semuanya berwarna hijau.

Keragaman genetik dari karakter lebar tajuk, panjang anter, bobot per buah dan panjang buah pada penelitian ini diklasifikasikan dalam kategori luas, sedangkan karakter bobot buah total per tanaman termasuk kategori sempit (Tabel 1). Hal ini sesuai dengan penelitian Ceron et al. (2012) yang menyatakan bahwa karakter buah memberikan kontribusi keragaman yang besar pada populasi Capsicum. Keragaman genetik yang luas pada populasi cabai rawit merah menjadi modal utama dalam program pemuliaan tanaman. Keragaman genetik yang tinggi pada karakter kuantitatif disebabkan oleh banyaknya gen pengendali yang bekerja pada karakter tersebut serta adanya perbedaan latar belakang genetik dari tiap aksesi (Santos et al., 2014; Syukur et al., 2011).

Nilai heritabilitas karakter lebar tajuk, panjang anter, bobot per buah, panjang buah, dan bobot buah total per tanaman berturut-turut adalah 77.48, 71.24, 88.04, 92.14, dan 77.02 (Tabel 1). Seluruh nilai heritabilitas tersebut termasuk dalam kategori tinggi. Hal tersebut berarti penampilan karakter yang diamati lebih dominan dipengaruhi oleh faktor genetik dibandingkan faktor lingkungan. Nilai duga heritabilitas yang tinggi dipadukan dengan keragaman genetik yang luas akan mempercepat proses seleksi terhadap karakter yang dikembangkan (Qosim et al., 2013), sehingga karakter yang sesuai untuk dijadikan karakter seleksi pada populasi ini adalah karakter lebar tajuk, panjang anter, bobot per buah, dan panjang buah.

Nilai tengah lebar tajuk dan panjang anter berkisar 59.35-103.52 cm dan 4.42-5.63 mm (Tabel 2). Genotipe yang memiliki lebar tajuk terbesar adalah C339 namun tidak berbeda nyata dengan C61, C163, C289, C290, C323, C330, C332, C337, C343, C344, C346, dan C350. Genotipe yang memiliki ukuran anter terbesar adalah C289 namun tidak berbeda nyata dengan C139, C163, C190, C290, C323, C330, C334, C339, C343, C344, C346, dan C350. Karakter lebar tajuk berkaitan dengan potensi munculnya bunga pada tiap percabangan. Lebar tajuk pada arsitektur tanaman Solanaceae diatur oleh gen pembungaan tunggal (Elitzur et al., 2009). Panjang anter berhubungan dengan potensi serbuk sari yang banyak, sehingga genotipe yang memiliki panjang anter lebih besar sesuai untuk dijadikan tetua jantan pada program persilangan tanaman.

Bobot per buah, panjang buah, dan bobot buah total per tanaman memiliki rentang nilai tengah berturut-turut 0.60-2.67 g, 2.01-5.44 cm, dan 14.68-155.09 g (Tabel 2). Bobot per buah terbesar pada C350 tidak berbeda nyata dengan C343, C289, dan C190. Genotipe C350 memiliki ukuran buah terpanjang $(5.44 \mathrm{~cm})$ namun tidak berbeda nyata dengan genotipe C343. Bobot buah total per tanaman paling berat dimiliki oleh C339 (155.09 g) namun tidak berbeda nyata dengan C344, C343, C337, C334, C330, dan C323.

\section{Ketahanan Cabai Rawit Merah terhadap Kutu Daun $\underline{A}$. gossypii}

Kondisi lingkungan mikro pada saat infestasi kutu daun $A$. gossypii mendukung pertumbuhan dan perkembangbiakan kutu daun $A$. gossypii sekaligus pertumbuhan tanaman cabai rawit merah. Populasi $A$. gossypii pada hari ke-28 setelah infestasi berkisar 3.00674.67 ekor per tanaman (Tabel 3). Berdasarkan kriteria ketahanan yang telah ditentukan dapat diketahui bahwa enam genotipe menunjukkan respon tahan terhadap A. gossypii (C332, C343, C333, C334, C290, C346), lima genotipe menunjukkan respon intermediet (C344, C337, C323, C61, C163), dan delapan genotipe menunjukkan respon rentan (C330, C190, C350, C139, C339, C295, C321, C289). Seluruh genotipe cabai rawit merah yang termasuk dalam kategori tahan terhadap kutu daun $A$. gossypii merupakan genotipe lokal, sedangkan genotipe hasil introduksi diklasifikasikan dalam kategori intermediet hingga rentan.

Tabel 1. Keragaman genetik dan heritabilitas karakter lebar tajuk, panjang anter, bobot per buah, panjang buah, dan bobot buah total per tanaman C. frutescens

\begin{tabular}{lccccc}
\hline \multirow{2}{*}{ Karakter } & \multirow{2}{*}{$\sigma^{2} \mathrm{G}$} & \multicolumn{2}{c}{$2 \sigma\left(\sigma^{2} \mathrm{G}\right)$} & \multicolumn{2}{c}{ Heritabilitas } \\
\cline { 3 - 6 } & & Nilai & Kriteria & Nilai & Kategori \\
\hline Lebar tajuk & 89.62 & 74.13 & Luas & 77.48 & Tinggi \\
Panjang anter & 0.14 & 0.13 & Luas & 71.24 & Tinggi \\
Bobot per buah & 0.36 & 0.26 & Luas & 88.04 & Tinggi \\
Panjang buah & 0.71 & 0.49 & Luas & 92.14 & Tinggi \\
Bobot buah total per tanaman & $1,712.08$ & $1,888.07$ & Sempit & 77.02 & Tinggi \\
\hline
\end{tabular}

Keterangan: $\sigma^{2} \mathrm{G}=$ ragam genetik, $\sigma\left(\sigma^{2} \mathrm{G}\right)=$ standar deviasi keragaman genetik 
Tabel 2. Rerata nilai karakter lebar tajuk, panjang anter, bobot per buah, panjang buah, dan bobot buah total per tanaman pada 19 genotipe cabai rawit merah (C. frutescens)

\begin{tabular}{|c|c|c|c|c|c|}
\hline Genotipe & $\begin{array}{l}\text { Lebar tajuk } \\
\quad(\mathrm{cm})\end{array}$ & $\begin{array}{l}\text { Panjang anter } \\
(\mathrm{mm})\end{array}$ & $\begin{array}{l}\text { Bobot per buah } \\
\text { (g) }\end{array}$ & $\begin{array}{l}\text { Panjang buah } \\
\quad(\mathrm{cm})\end{array}$ & $\begin{array}{l}\text { Bobot buah total } \\
\text { per tanaman } \\
\text { (g) }\end{array}$ \\
\hline C61 & $92.25 \mathrm{a}-\mathrm{d}$ & $4.65 \mathrm{~cd}$ & $0.63 \mathrm{fg}$ & $2.70 \mathrm{fgh}$ & $48.21 \mathrm{de}$ \\
\hline C139 & $59.35 \mathrm{e}$ & $4.89 \mathrm{a}-\mathrm{d}$ & $0.63 \mathrm{fg}$ & $2.67 \mathrm{fgh}$ & $56.36 \mathrm{cde}$ \\
\hline $\mathrm{C} 163$ & $86.54 a-d$ & $5.33 \mathrm{abc}$ & $1.21 \mathrm{efg}$ & $3.78 \mathrm{cde}$ & 63.66b-e \\
\hline C190 & $100.53 \mathrm{a}$ & $4.82 \mathrm{a}-\mathrm{d}$ & 2.19a-d & $2.97 \mathrm{fg}$ & $35.34 \mathrm{de}$ \\
\hline C289 & 89.35a-d & $5.63 \mathrm{a}$ & $2.57 \mathrm{ab}$ & $3.35 \mathrm{def}$ & $61.97 \mathrm{~b}-\mathrm{e}$ \\
\hline C290 & $90.02 \mathrm{a}-\mathrm{d}$ & $5.32 \mathrm{abc}$ & $1.83 \mathrm{cde}$ & $3.84 \mathrm{cde}$ & $63.28 \mathrm{~b}-\mathrm{e}$ \\
\hline C295 & $75.94 d$ & $4.80 \mathrm{bcd}$ & $1.37 \mathrm{e}$ & $3.19 \mathrm{ef}$ & $48.41 \mathrm{de}$ \\
\hline C321 & $75.12 \mathrm{~d}$ & $4.47 \mathrm{~d}$ & $1.42 \mathrm{e}$ & $3.42 \mathrm{def}$ & $42.72 \mathrm{de}$ \\
\hline C323 & $98.56 \mathrm{ab}$ & $5.61 \mathrm{ab}$ & $1.25 \mathrm{efg}$ & $3.94 \mathrm{cde}$ & $133.06 \mathrm{ab}$ \\
\hline C330 & $93.51 \mathrm{abc}$ & $5.35 \mathrm{abc}$ & $1.27 \mathrm{efg}$ & $4.52 \mathrm{bc}$ & $95.10 \mathrm{a}-\mathrm{d}$ \\
\hline C332 & $99.89 \mathrm{ab}$ & $4.42 \mathrm{~d}$ & $0.60 \mathrm{~g}$ & $2.35 \mathrm{gh}$ & $30.30 \mathrm{de}$ \\
\hline C333 & $77.21 \mathrm{~cd}$ & $4.36 \mathrm{~d}$ & $0.63 \mathrm{fg}$ & $2.01 \mathrm{~h}$ & $14.68 \mathrm{e}$ \\
\hline C334 & $93.92 \mathrm{abc}$ & $5.56 \mathrm{ab}$ & $1.86 \mathrm{cde}$ & $4.18 \mathrm{bcd}$ & $145.82 \mathrm{a}$ \\
\hline C337 & $95.94 \mathrm{ab}$ & $4.64 \mathrm{~cd}$ & $1.35 \mathrm{ef}$ & $3.42 \mathrm{def}$ & $124.55 \mathrm{abc}$ \\
\hline C339 & $103.52 \mathrm{a}$ & $5.45 \mathrm{abc}$ & $1.55 \mathrm{de}$ & $4.41 b c$ & $155.09 \mathrm{a}$ \\
\hline C343 & $88.77 \mathrm{a}-\mathrm{d}$ & $5.61 \mathrm{ab}$ & $2.33 \mathrm{abc}$ & $4.90 \mathrm{ab}$ & $149.52 \mathrm{a}$ \\
\hline C344 & $89.94 a-d$ & $4.88 \mathrm{a}-\mathrm{d}$ & $1.91 \mathrm{~b}-\mathrm{e}$ & $4.13 \mathrm{bcd}$ & $146.70 \mathrm{a}$ \\
\hline C346 & $83.02 \mathrm{bcd}$ & $5.30 \mathrm{abc}$ & $1.49 \mathrm{de}$ & $3.96 \mathrm{cde}$ & 39.37de \\
\hline C350 & $86.54 a-d$ & $5.56 \mathrm{ab}$ & $2.67 \mathrm{a}$ & $5.44 \mathrm{a}$ & $57.09 \mathrm{cde}$ \\
\hline
\end{tabular}

Keterangan: Angka yang diikuti huruf yang sama pada kolom yang sama menyatakan tidak berbeda nyata pada uji lanjut DMRT taraf 5\%

Hal ini menunjukkan bahwa sumber ketahanan terhadap kutu daun $A$. gossypii diduga lebih banyak terdapat pada genotipe lokal.

Genotipe cabai rawit merah yang tahan $A$. gossypii tidak memerlukan pengendalian hama karena diduga tidak menimbulkan kerusakan signifikan (Moekasan et al., 2015). Tanaman yang tahan terhadap kutu daun dapat menjaga stabilitas transpirasi dan kandungan air serta gula pada tanaman (Sun et al., 2016). Pada genotipe C344, C337, C323, C61, C163, C330, C190, C350, C139, C339, C295, C321, C289 perlu dilakukan pengendalian hama untuk mengurangi persentase kehilangan hasil (Moekasan et al., 2015; Sudrajat, 2008).

Tanaman cabai rawit merah dengan kategori tahan dalam penelitian memiliki mekanisme antibiosis lebih baik dari tanaman rentan ditunjukkan oleh populasi kutu daun yang berjumlah $<20$ individu per tanaman. Mekanisme antibiosis bekerja ketika hama telah hinggap pada tanaman dan melakukan proses biologi serta tidak memiliki kesempatan untuk memilih tanaman lain sebagai inangnya. Chrompton dan Ode (2010) menyatakan bahwa mekanisme antibiosis dapat membatasi populasi kutu daun pada semua tahap pertumbuhan tanaman. Mekanisme antibiosis pada tanaman dipengaruhi oleh adanya metabolit sekunder pada jaringan floem (Zust dan Agrawal, 2016). Le Roux et al. (2008) menemukan bahwa metabolit sekunder yang berperan dalam antibiosis adalah fitotoksin glikosida steroid. Da Costa et al. (2011) menemukan senyawa volatile organik compounds (VOCs) berupa asam propanoat, undecanol, pentanon tridekana, undecenoic acid, metil hepten, octanoid acid berperan dalam pertahanan cabai terhadap kutu daun.

\section{Potensi Hasil dan Ketahanan Kutu Daun}

Biplot karakter bobot buah total per tanaman dan populasi A. gossypii (Gambar 2) digunakan untuk memilih genotipe yang potensial dikembangkan dalam pemuliaan tanaman cabai rawit merah yang tahan kutu daun. Genotipe yang terpilih adalah C343 dan C334. Keunggulan genotipe terpilih adalah memiliki karakter bobot buah total per tanaman lebih tinggi dari rataan umum dan memiliki respon tahan terhadap A. gossypii.

Genotipe C343 dan C334 memiliki bobot buah total per tanaman berturut-turut $149.52 \mathrm{~g}$ dan $145.82 \mathrm{~g}$. Potensi produktivitas kedua genotipe tersebut dapat mencapai 2.9 ton per hektar. Jumlah tersebut dapat meningkat apabila genotipe C343 dan C334 dijadikan tetua persilangan untuk mendapat genotipe yang lebih tinggi produktivitasnya. 
Riti et al. / J. Agron. Indonesia 46(3):290-297

Tabel 3. Populasi A. gossypii hari ke-28 setelah infestasi pada 19 genotipe $C$. frutescens beserta kriteria ketahanannya

\begin{tabular}{lccl}
\hline Genotipe & $\begin{array}{c}\text { Rerata jumlah A. gossypii } \\
\text { per tanaman }\end{array}$ & SE & Kriteria \\
\hline C332 & 3.00 & 3.00 & Tahan \\
C343 & 6.33 & 3.18 & Tahan \\
C333 & 7.67 & 3.76 & Tahan \\
C334 & 18.33 & 3.76 & Tahan \\
C290 & 19.33 & 19.33 & Tahan \\
C346 & 19.33 & 18.84 & Tahan \\
C344 & 16.25 & Intermediet \\
C337 & 29.67 & 33.27 & Intermediet \\
C323 & 37.67 & 29.29 & Intermediet \\
C61 & 55.67 & 43.52 & Intermediet \\
C163 & 61.00 & 45.86 & Intermediet \\
C330 & 13.87 & Rentan \\
C190 & 62.67 & 60.83 & Rentan \\
C350 & 65.33 & Rentan \\
C139 & 74.50 & 102.01 & Rentan \\
C339 & 104.00 & 93.63 & Rentan \\
C295 & 110.33 & Rentan \\
C321 & 127.33 & Rentan \\
C289 & 145.33 & 136.43 & Rentan \\
\hline
\end{tabular}

Keterangan: Tahan $(0-\leq 20)$, intermediet $(21-\leq 63)$, rentan $(\geq 64)$ ekor per tanaman, $\mathrm{SE}=$ standar eror

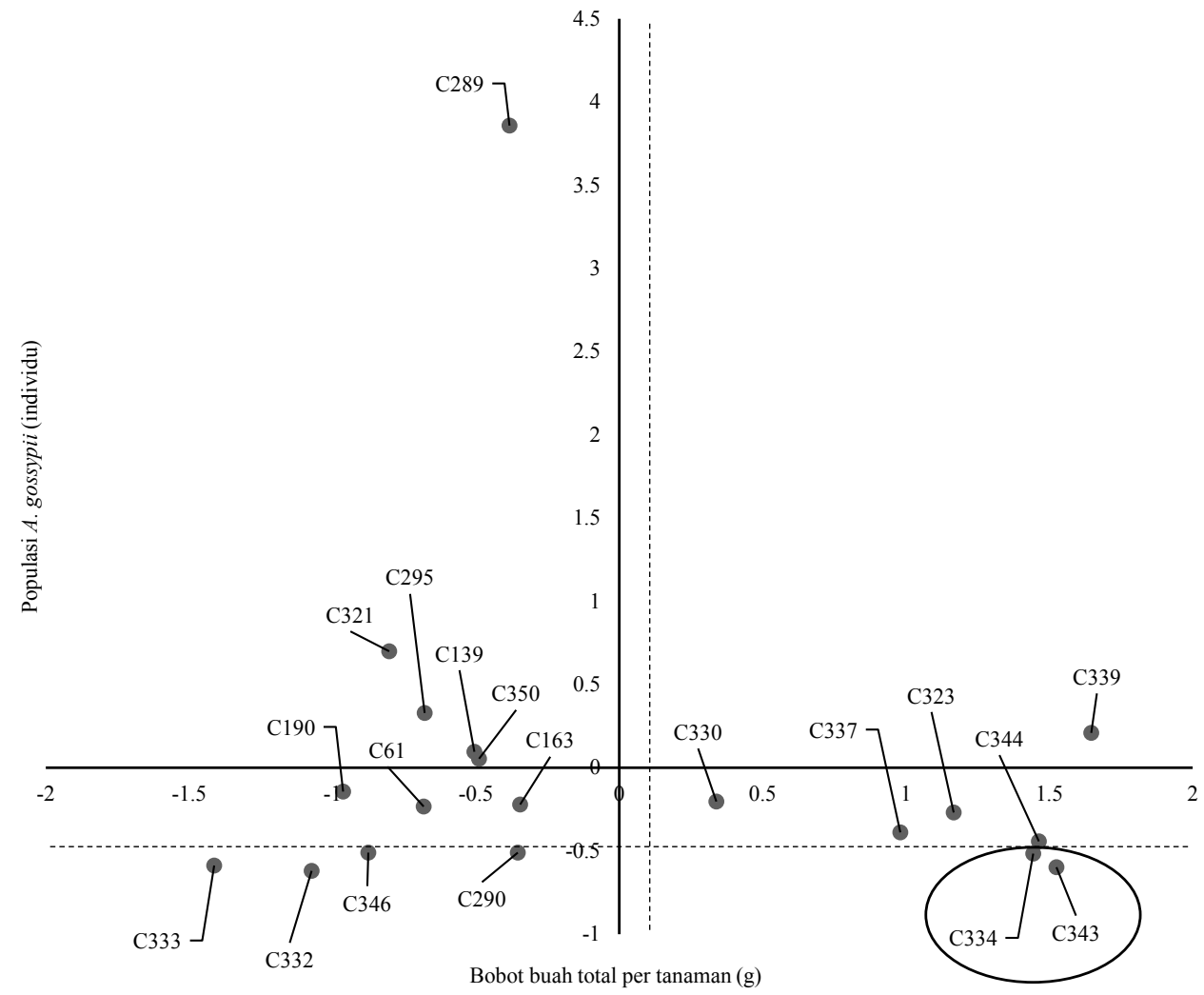

Gambar 2. Biplot karakter bobot buah total per tanaman dan populasi A. gossypii. Genotipe yang berada di sebelah kanan garis putus-putus adalah genotipe yang memiliki bobot buah total per tanaman tinggi. Genotipe yang berada di bawah garis putus-putus adalah genotipe yang tahan terhadap $A$. gossypii 


\section{KESIMPULAN}

Keragaman 19 genotipe cabai rawit merah memiliki koefisien ketidakmiripan lebih dari 0.30 (30\%). Ragam genetik karakter lebar tajuk, panjang anter, bobot per buah, panjang buah termasuk kategori luas, sedangkan bobot buah total per tanaman termasuk kategori sempit. Berdasarkan hasil uji penapisan dapat diketahui bahwa genotipe cabai rawit merah yang tahan terhadap kutu daun $A$. gossypii adalah C290, C332, C333, C334, C343, dan C346. Genotipe C343 dan C334 memiliki potensi untuk dikembangkan sebagai varietas unggul baru (VUB) cabai rawit merah yang tahan terhadap kutu daun A. gossypii dan berdaya hasil tinggi (2.9 ton per hektar).

\section{UCAPAN TERIMA KASIH}

Penulis mengucapkan terima kasih kepada Kementrian Riset, Teknologi, dan Pendidikan Tinggi atas bantuan dana penelitian melalui program Hibah Kompetensi tahun 2016 a.n. Prof. Dr. Muhamad Syukur, SP. MSi (Nomor kontrak: 079/SPZH/LT/DRPM/II/2016).

\section{DAFTAR PUSTAKA}

Blackman, R.L., V.E. Eastop. 2000. Aphids on The World's Crops: Identification and Information Guide. $2^{\text {nd }}$ Edition. John Wiley \& Sons Ltd, England, GB.

Buyinza, M., F. Mugagga. 2010. Economic viability of hot pepper (Capsicum frutescens L) cultivation in agroforestry farming system in Kamuli District, Uganda. J. Innov. Dev. Strat. 4:12-17.

Ceron, D.V., M.L.B. Betancourt, H.C. Carrillo, J.J. Vasquez, M.A.G. Davila. 2012. Morphological characterization of Capsicum spp. accessions from the germplasm collection of Corpoica C.I. Palmira, Colombia. Acta Agron. 61:16-26.

Chrompton, D.S., F.J. Ode. 2010. Feeding behavior analysis of the soybean aphid (Hemiptera: Aphididae) on resistant soybean 'Dowling'. J. Econ. Entomol. 103: 648-653.

Da Costa, J.G., E.V. Pires. A. Riffel, M.A. Birkett, E. Bleicher, A.E.G. Sant'Ana. 2011. Differential preference of Capsicum spp. cultivars by Aphis gossypii is conferred by variation in volatile semiochemistry. Euphytica 177:299-307.

Daryanto, A., M. Syukur, P. Hidayat, A. Maharijaya. 2017a. Antixenosis and antibiosis based resistance of chili pepper to melon aphid. J. Appl. Horti. 19:147-151.

Daryanto, A., M. Syukur, A. Maharijaya, P. Hidayat. 2017 b. Pewarisan sifat ketahanan cabai terhadap infestasi
Aphis gossypii Glover (Hemiptera: Aphididae). J. Hort. Indonesia 8:39-47.

Dutta, S.K., S.B. Singh, Vanlalhmangaiha, A. Banerjee, R.S. Akoijam, T. Boopathi, S. Saha, S. Roy. 2017. Capsicum frutescens L. landraces of North-East India: from phenotypic diversity perspective of unexplored collection. Proc. Natl. Acad. Sci. Doi: 10.1007/s40011-017-0850-3.

Elitzur, T., H. Nahum, Y. Borovsky, I. Pekker, Y. Eshed, I. Paran. 2009. Co-ordinate regulation of flowering time, plant architecture and growth by FASCICULATE: the pepper orthologue of SELF PRUNING. J Exp Bot. 60:869-880.

Hakim, A., M. Syukur, Y. Wahyu. 2018. Evaluasi karakter kualitatif dan kuantitatif 20 genotipe cabai rawit merah (Capsicum frutescens L.) koleksi IPB. J. Comm. Horticulturae 2:20-27.

Kanakala, S., M. Ghanim. 2016. RNA interference in insect vectors for plant viruses (review). Viruses 8:239. Doi $: 10.3390 / \mathrm{v} 8120329$.

Le Roux, V., S. Dugravot, E. Campan, F. Dubois, C. Vincent, P. Giordanengo. 2008. Wild Solanum resistance to Aphids: Antixenosis or antibiosis?. J. Econ. Entomol. 101:584-591.

Lima, M.F., S.I.C. Carvalho, C.F. Ragassi, L.B. Bianchetti, F.G. Faleiro, F.J.B. Reifschneider. 2017. Characterization of a pepper collection (Capsicum frutescens L.) from Brazil. Genet. Mol. Res. 16:118.

Maharijaya, A. 2013. Resistance to thrips in pepper. Disertasi. Wageningen University. Wageningen.

Moekasan, T.K., N. Gunadi, W. Adiyoga, I. Sulastrini. 2015. Kelayakan teknis dan ekonomi budidaya cabai merah di dalam rumah kasa untuk menanggulangi serangan organisme pengganggu tanaman. J. Hort. 25:180192.

Nelly, N., Yaherwandi, M.S. Effendi. 2015. Keanekaragaman Coccinelidae predator dan kutu daun (Aphididae spp.) pada ekosistem pertanaman cabai. Pros. Sem. Nas. Masy. Biodiv. Indon. 1:247-253.

Nuryati, L., B. Waryanto, R. Widaningsih. 2016. Outlook Komoditas Pertanian Sub Sektor Hortikultura Cabai. Pusdatin Kementan, Jakarta, ID.

Qosim, W.A., M. Rachmadi, J.S. Hamdani, I. Nuri. 2013. Penampilan fenotipik variabilitas, dan heritabilitas 32 genotipe cabai merah berdaya hasil tinggi. J. Agron. Indonesia 41:140-146. 
Saljoki, A.R., S. Ali, S. Rehman. 2013. Population dynamics of Aphis gossypii (Glover) and its associated natural enemies in different okra varieties. Pakistan. J. Zool. 45:1197-1205.

Sanatombi, K., G.J. Sharma. 2008. Capsaicin content and pungency of different Capsicum spp. cultivars. Not. Bot. Hort. Agrobot. Cluj. 36:89-90.

Santos, R.M.C., E.R. do Rego, A. Borem, M.F. Nascimento, N.F.F. Nascimento, F.L. Finger, M.M. Rego. 2014. Epistasis and inheritance of plant habit and fruit quality traits in ornamental pepper (Capsicum anuum L.). Gen. Mol. Res. 13:8876-8887.

Sudrajat. 2008. Hubungan antara kepadatan populasi kutu daun persik (Myzus persicae Sulz.) dan tingkat kerusakan daun dengan kehilangan hasil cabai merah (Capsicum annuum L.). J. Agrikultura 19:191-197.

Sukada, I.W., I.M. Sudana, I.D.N. Nyana, G. Suastika, K. Siadi. 2014. Pengaruh infeksi beberapa jenis virus terhadap penurunan hasil pada tanaman cabai rawit (Capsicum frutescens L.). E-J Agroekotekno. Trop. 3:158-165.

Sun, Y., H. Guo, F. Ge. 2016. Plant-aphid interactions under elevated $\mathrm{CO}_{2}$ : Some cues from aphid feeding behavior. Front. Plant Sci. 7:1-10.

Syukur, M., S. Sujiprihati, R. Yunianti, D.A. Kusumah. 2011. Pendugaan ragam genetik dan heritabilitas karakter komponen hasil beberapa genotipe cabai. J. Agrivigor 10:148-156.

Syukur, M., S. Sujiprihati, R. Yunianti. 2015. Teknik Pemuliaan Tanaman. Edisi Revisi. Penebar Swadaya, Jakarta, ID.

Undang, M. Syukur, Sobir. 2015. Identifikasi spesies cabai (Capsicum spp.) berdasarkan daya silang dan karakter morfologi. J. Agron. Indonesia 43:118-125.

Zust, T., A.A. Agrawal. 2016. Mechanisms and evolution of plant resistance to aphids. Nat. Plants 2:1-9. 